\section{SHERPA BUDDHISTS ON A REGIONAL PILGRIMAGE : THE CASE OF MARATIKA CAVE AT HALASE ${ }^{1}$}

\section{Eberhard Berg}

\section{The Subject of this Paper}

Nowadays it seems to be a well established fact within the scientific community that Buddhist - as well as Hindu - pilgrimages may be studied as an ancient socioreligious institution sustaining a system of interrelated holy centers. In the case of Buddhism this system helps to bind together diverse peoples of South and Central Asia. According to the results of the last decade of empirical research as well as in theoretical discourse, pilgrimages, represent a distinct kind of ritual performance with a broad range of corresponding processes of social interaction.

Halase in Eastern Nepal is a popular pilgrimage quest for Hindus and Buddhist alike. It is characterized by an almost complete lack of institutionalized formal religious structures. That specific condition endows this sacred center with its very distinctiveness. Apart from these circumstances it is worth mentioning that still today there seems to be very little known concerning Halase and the diverse pilgrimages connected with this holy locale. ${ }^{2}$

In this paper I am not trying to find a means of generalizing on the almost worldwide phenomenon of pilgrimage by investigating a specific case. Rather, I am exploring the various aspects of a specific case of pilgrimage in order to illuminate its particularity: the Sherpa pilgrimage to Halase on occasion of 'losar', the Tibetan New Year Festival.

Thus this paper is an examination of the diverse ways Sherpa Buddhist pilgrims united within one single religious tradition approach and 'appropriate' a holy place which they share not only with each other but also with diverse groupings of Hindu devotees. Accordingly, it aims at exploring various aspects of the Sherpa Buddhist pilgrimage to Halase, focussing primarily on two questions: (a) the forms of social interaction emerging between groups of Sherpa pilgrims as well as between Sherpa and other pilgrims, and (b) the various ritual performances which characterize the whole process of the Sherpa pilgrimage to Maratika cave.

Mention must be made of the fact that this holy place is situated beyond the confines of Solukhumbu, their familiar territory, thus necessitating a crossregional pilgrimage.

\section{Sherpas and Tibetan Buddhism}

The Sherpas are an ethnically Tibetan group in northeast Nepal, the majority of whom live at high altitudes in the valleys of Solukhumbu region. They trace their origin to a group of clans who had moved from Kham in northeastern Tibet due to conflicts with Mongolian invaders. This movement came to a halt when the Sherpas settled in Khumbu, Pharak, and Solu in the late fifteenth and the early sixteenth centuries. ${ }^{3}$

The distinctiveness of Sherpas in relation to other ethnic groups of Tibetan stock is well established. ${ }^{4}$ Culturally, however, the Sherpas are Tibetan. Their way of life is in most respects Tibetan; they speak a Tibetan dialect; and as adherents to the unreformed Nyingmapa order their whole lives are deeply embedded in Tibetan Buddhism. Sherpa pilgrimage can only be understood in the context of the Buddhist textual tradition and the Nyingmapa in particular. ${ }^{5}$ This implies that existing knowledge as to how to encounter the gods and goddesses associated with a holy center and what to expect from a pilgrimage to this site, which kind of rituals to be performed in a distinct sequence and which prayers to be recited there is, at least basically, guided by specific texts. The ordinary laypeople whom I was mainly travelling together with revealed a varying degree of 'previous' knwoledge about Halase and the mythology connected with this place of pilgrimage; in other words they were informed somehow, either by conversation with those who had been there before or by own experience and/or by the books themselves usually mediated by a lama or a monk.

\section{Why the Buddhist Sherpas Use to Go on Pilgrimage}

'To gain' or 'to accumulate merit' was the usual answer to all my questions relating to the central problem of what makes the Sherpa individual decide upon 
going on a pilgrimage. ${ }^{6}$ This seems to be the key metaphor not only in Sherpa Buddhist society which morally guides the individual's acting. ${ }^{7}$ Thus without a clear idea of this concept of 'merit' which among the Sherpas - as well as among other Buddhist peoples - also represents the crucial motivation for going on pilgrimage an adequate understanding of this particular form of socioreligious process cannot be reached.

The acquisition of 'merit' (Sherpa 'sonam', meaning 'good karma) at an individual level is a constant theme of Sherpa life, as it is with Tibetans and also with Theravada Buddhists in Burma and Thailand. According to Buddhist tradition the accumulation of 'merit' through performing good actions such as financial donations to monasteries and lamas, becoming a monk, giving food to lamas and monks and avoiding bad actions is the primary religious duty specified for the laypeople. The building up of merit is thought to counteract the efffects of sinful deeds committed and to ensure a happier rebirth. ${ }^{8}$ According to my informations the practice of certain religious activities among the Sherpas like going on pilgrimage aim at both accumulating merit for the future life as well as gaining benefits in this world; in other words it comprises inner-worldly motives and those transcending the constraints of this world.

Lamas, monks, and nuns as well as laypeople can acquire merit by prayers, by recitation of scriptures, by putting up prayer flags, by moving the prayer wheels, by offering butter lamps and burning incense before the temple images, by prostrations, by making repeated circumambulations of religious buildings and by many other ritual performances. Laypeople can al so accumulate merit by giving alms to the poor. Highly valued are such acts as building bridges and rest-houses, mediating as peace-maker. Even more respected ways of gaining merit consist in giving gifts to lamas, monks, and nuns. It is particularly meritorious, however, to give donations for the support of a monastery and for the construction or repair of religious buildings such as temples, shrines, 'maniwalls' and 'chorten' (Sherpa 'stupa'; circular edifices containing religious relics).

All those acts are regarded as meritorious because of their benefit to the community as a whole. One of the foremost important modes to gain merit in Sherpa society, however, consists in going on a pilgrimage. But even this way of gaining merit individually produces some sort of 'benefit' to the whole of the local community.

As will be shown, however, the act of going on a pilgrimage does not represent a wholly religious affair. To the Buddhist motif of accumulating merit clearly add more inner-worldly ones easily summarized as the wish for health, wealth, and progeny. Yet there is also a wholly different aspect involved lending its distinct flavour to the individual's pilgrimage experience. During the pilgrimage process there is much to be seen on the way, many people to be met, and there are many teastalls by the road offering also rakshi and 'chang'. And on the margin of the holy center there is usually a bazaar with a range of goods, however limited, coming from as far as India and/or Tibet. And there can be found numerous teastalls, representing an important 'profane' social arena in close association with the realm of sacred space. At those teastalls many of the pilgrims present, especially the younger people, like to spend the whole night drinking, singing, and dancing. Thus, in most cases pilgrimage seems to constitute a particular space of time which usually is experienced by the laypilgrim both as 'holy day' and as 'holiday'. Accordingly, the motif of the average Sherpa for going on a pilgrimage usually is of dual character though when being questioned the answer usually omits the fascination of this very this social aspect of the pilgrimage process.

\section{The Setting of the Holy Place of Halase}

Halase is a holy place in Eastem Nepal visited by Hindu and Buddhist devotees alike. This important place of pilgrimage is situated in Khotang District in the hills south-east of Okhaldhunga at about one long day's walking distance. Not unimportantly its exact location is just alongside the main trade-route connecting Katari Bazaar in the south with Bhojpur via Diktel village.

It is the dramatic natural setting - a hill covered with trees consisting of two uninterrelated limestone caves - which gives this pilgrimage locale its very distinctive character. There is only one formal (Hindu) shrine but no statues within a setting of wonderous and enigmatic natural formations lending themselves to impose arious meanings on them.

The bulk of the numerous Hindu pilgrims visiting Halase is made up of caste-groups such as Brahmin and Chhetri as well as ethnic hills-people such as $\mathrm{Rai}$, Lumbu, and Magar. According to my informations this place of pilgrimage is visited four times a year by Hindus (at Bala Chaturdasi, at Ram Navami, at Tij and at Sivaratri ${ }^{9}$ - which I witnessed twice on March 2nd 1992 and on February 19th, 1993. And it is interesting that Halase is regarded by the Hindu villagers of the area (predominantly Rai, others are Brahmin and Chhetri) as their most popular site of pilgrimage to be visited on occasion of the big jatras..$^{10}$ As to Hindu pilgrims the catchment area of Halase seems to consist of a wide area 
including the foothills as well as the lowlands of the Terai.

The same place is the holy center of a pilgrimage by Tibetans as well as by Tamang and Sherpa Buddhists from Solukhumbu who use to gather there once a year - usually in February - on the occasion of Losar, the Tibetan as well as the Sherpa New Year. The Tibetan population of the Dingri area just north of Khumbu and Sagarmatha traditionally have had close economic ties with Solukhumbu, Kathmandu Valley, and the southern lowlands. Apart from regular trading ventures the population of Dingri and the Sherpas of Solukhumbu used to share particular pilgrimages like that to Halase in the south or north to Tsibri in the Dingri region. 11

On the margin of this sacred space there is located a bazaar of regional importance being held not only on occasion of a pilgrimage but also weekly on every monday. Apart from food and drinks such as tea and locally brewed alcohol - but neither imported beer nor 'coke' and the like - this market offers a variety of goods especially from the Terai and northern India to pilgrims and to the local population. Due to these various aspects, the pilgrimages to Halase four times a year give this holy place a distinct and very complex social organization.

It must be mentioned in this context, however, that, unlike those holy sites in remote areas connected with mountain peaks and glacier lakes regarded as the seat as well as the physical representation of the regional protective deities, Halase is not difficult to reach. For Hindus coming from the Terai and the whole southeastem part of Nepal and for Buddhist pilgrims from Solukhumbu the travel to this holy place involves a journey on foot of between four and eight days to reach there and return home. Khumbu Sherpas on pilgrimage to Maratika cave usually follow the ax is of the Dudh Kosi valley remaining on its east side for most of the journey. Solu Sherpas and Tibetans from the Chalsa refugee settlement, on the other hand, reach this sacred locale via Okhaldhunga.

Still today there seems to be known only very little concerning Halase and the different pilgrimages connected with this pilgrimage center. As the pilgrimage to Halase as well as the holy place itself have until now been almost completely ignored by scientific researches, there exist only few written comments. 12

\section{Mythic Origins of Maratika Cave at Halase}

Apart from the mythical stories connected with a holy place and its origin an important feature of a sacred center usually is represented by its specific geological nature. Of central importance here is a specific combination of the geological characteristics of an enormous stalactite cave and selected mythologemes which are interpreted by the informed pilgrim according to the oral and written - traditions legitimating, encouraging, necessitating the socioreligious practice of a pilgrimage.

According to the differing religious traditions concerning the holy center of Halase Hindus and Buddhists hold true different versions considering the mythological origin of the holy place in question. In each religious system this pilgrimage site is associated with a specific mainfestation of the divine. Those enigmatic and wonderous geological creations to be found in Halase are regarded in mythology as manifestations of gods and - in the case of Buddhists - of goddesses having spent some of their time there for meditation in retreat.

For Hindus Halese is an important place of pilgrimage because of the famous shrine of Mahadev 13 which is situated at the bottom of the cave. Mahadev is said to have manifested himself here in the form of a natural 'linga' being nowadays enshrined. It must be mentioned that in the spatial contest of the sacred cave this shrine represents the only man-made religious structure.

Among Buddhists the sacred center of Halase is known as Maratika cave. Most of the Buddhist pilgrims questioned concerning the mythic origin of this sacred locale refer to Maratika cave as the site where the famous tantric sage Guru Padmasambhava once had stayed at for retreat before making his way up to Tibet ${ }^{14}$ in his pursuit to introduce Buddhism there. Its distinct sacredness, however, is due to the following legend which seems to transcend the knowledge of the average laypeople. Buddhist tradition holds true that Guru Padmasambhava and Mandarava, 15 the Indian princess from Mandi and one of his main consorts, had practiced and mastered the long life practice called 'cedrub gondus' ('the union of primordial essence') together at this unique cave site. ${ }^{16}$ Thus, this holy site is important to the adherents of Nyingmapa Buddhists in that it is illustrative of a crucial part in the life of Guru Padmasambhava and his famous consort Mandarava. The aura of holiness which emanated from the legendary presence of the mythical culture hero and this dakini and the specific practices performed there has been transmuted into a spatial sacredness anchored in this place and sanctified by their presence.

Those deities are to be revered according to a specific time-schedule by presenting offerings, prayers, performing poojas, and -in the case of the Buddhist pilgrims - by circumambulating this holy inner center as well as the whole hill. 
By journeying to this powerful sacred center, by offering gifts to these deities, and by performing certain ritual practices there pilgrims obtain the realization of their very individual goal.

What can they expect from going on pilgrimage to Maratika cave ? According to the texts it seems to guarantee fairly much to the devote pilgrim. Alexander MacDonald (p.9) cites a guide-book copied, translated and presented by Barbara Aziz specifying the particular merit to be gained at halase. There she writes: "As soon as one visits this sacred place Ha-la-shes, one is assured of not being reborn in one of the bad realms. As soon as one hears (of its virtues), one is purified from the five sinful acts and pollutions." - Apart from this it should be kept in mind that the framework of the investigation presented here focussing upon Sherpa Buddhist ritual practices during a specific pilgrimage has to deal with the fact that the 'setting' of Halase as a holy place of pilgrimage comprises two - Buddhist and Hindu - realities.

\section{Sherpa Pilgrims on the Road to Maratika Cave}

The majority of the Sherpas on pilgrimage to Halase I encountered were travelling in fairly large groupings. In most cases witnessed, these groupings consisted of both sexes and members of the three generations. They comprised between eight and twentyone people. Usually the pilgrims of one grouping were not only bound together by a shared purpose but also by affinal relations and by the same locality. Sometimes a group of pilgrims included also an individual's personal friend. Sherpas starting out as singles very often join a group in the course of their peregrination. Another striking aspect was that very often these groupings were lacking Sherpamen of the middle generation. Usually those Sherpa men of middle age were hindered from taking part in this social event due to their diverse obligations in the trekking business.

Occasionally a group of Sherpa pilgrims was accompanied by a monk and/or a nun who were also relatives. Without any doubt their presence in the group provided some spiritual touch. But in no case I witnessed any kind of spiritual leadership of a Sherpa pilgrimage grouping.

Sometimes sick people travel amidst their relatives to a holy place hoping for being cured by this venture. This seems to represent another albeit only occasional feature of a pilgrimage. For example, on my first journey to Halase on occasion of 'losar' 1992, I met a big group of sixteen people from Goli in Solu. One of the male members was a very old man who due to some sickness had to make the two and a half days' travel to Maratika cave on horseback. His nicely decorated horse had to be led all the way by one of the his male relatives. Without any doubt travelling in this area under these circumstance must be a very uncomfortable task.

If they can manage, Sherpa pilgrims to Halase spend a night at a relative's house. But due to the fact that one has to spend at least two nights outside Solukhumbu before reaching the pilgrim's goal most of the groups encountered on the road stayed out over night. They preferred sites suitable to the needs of being on the road where they could camp, cook their own food carried all the way, and stay for themselves without disturbances arising from 'outside'. It seemed to be a remarkable feature of all Sherpa pilgrimage groupings I encountered in this context that they were very well organized for those purposes. Thus deliberately avoiding the overly spending of money Sherpa pilgrimage to Maratika cave does not seem to necessitate any considerable financial resources nor does it involve any minutious preparations beforehand of any sort. The specific way of their acting as pilgrims on the road, however, resulted also in a social effect of another sort: communication with people of diverse origin other than Sherpa met on their way to the holy center like porters, traders, local villagers etc. seemed to be restricted to a striking minimum. Apart from teastalls there did not appear much realm for social interaction with other people on the way, and even these short moments of trying to relate to others seemed to be dictated predominantly by necessity. By contrast, intra-group communication seemed to be all the more lively. It was generally characterized by a continuous flux of merry talking among the diverse sub-groupings usually emerging on the road either by conscious acting or just accidentally.

The track from Solukhumbu to Halase neither provides a great mental nor a great physical challenge to Sherpa pilgrims. Neither are there dangerous gorges and difficult high passes nor are there any religious buildings like temples or monasteries to be visited by the road. Coming from Solu there is only one pass of about $2,800 \mathrm{~m}$ height to be traversed. To mountain people whose life-style since several centuries has been well-adapted to high altitude areas this small pass does not pose any serious problem. Apart from these circumstances the fair weather around 'losar' makes the pilgrimage to Halase an enjoyable journey.

The only situation where for a short period a serious individual 'crisis' became manifest arose while crossing the Dudh Kosi by a small canoe. This shaky means of transportation across unknown waters and tricky currents could only take up to six people including luggage at the time. While waiting for one's 
own term to come and watching their fellow pilgrims handling this seemingly unknown and dangerous crossing by boat the usual way of laughing and merry talking became tinged with a slight nervous overtone. For the duration of this undertaking especially old people both men and women used to pray continuously and to snap drops of water with their ring-finger over the head as if they were trying to appease the unknown powers of this river. This seemed to represent an encounter characterized by an obvious breakdown of the routine guiding the individual's acting in everyday-life.

Yet the crossing of the Dudh Kosi by means of a small shaky canoe represents the only obstacle on the way to Halase which to overcome Sherpas traditionally do not seem to be accustomed to. And aprt from this the movement of the Sherpa pilgrims across the landscape to Halase does not seem to evolve within a symbolically charged realm. By comparison with, for example, the pilgrimages within the Dolpo area, as reported by Corneille Jest, ${ }^{17}$ the movement of the Sherpa pilgrim groupings encountered on the way from Solu to Halase does not seem to be strongly ritualized.

\section{Approaching the Holy Site}

The way to Halase I was travelling together with a Sherpa pilgrimage grouping from Ringmo in Solu. Their group consisted of seven women, four of whom of old age, three of them young, two of which married including a small kid each and four men, three old and one only young man married with one of the young women.

The hills around Halase are steep. This notwithstanding the terrain does not pose any serious problems to people who are accustomed to travel extensively on foot. However, the sight of the impoverished red and ochre soil and, due to its barrenness, the poor vegetation of the whole region was striking not only to me.

The final approach to the sacred center of Halase is signalled to the pilgrim by a hill densely covered by trees. Already at some distance the gazing eye recognizes that this hill is one of the very few forested hills in the whole region. This landmark is the more obvious as many of the trees covering the hilltop are decorated by countless coloured prayer-flags heralding Maratika cave to pilgrims as well as to travellers already from afar.

The holy center is represented by this hill consisting of two uninterrelated caves. The one cave of about $120 \mathrm{~m}$. length situated at the bottom of the hill does not seem to be of much importance neither to Buddhists nor to the Hindus present. Only at three minor sites in the dark few burning candles, butter lamps, and incense testified that poojas must be held here. I personally witnesssed mostly visitors curiously discovering the site like visitors of a museum do. Before entering this cave one has to blow into a small hole in the rock on the left side which results in a deep sound resembling, for example, that of a conch-shell used in Buddhist gompa rituals. At its end there is a platform which looking upwards gives way to the sight of the blue sky through an enormous hole in the 'ceiling' of this cave. One its one side there are a few 'om mani padme hum' including a stupa engraved in the rock.

From the bottom of the hill the pilgrim proceeds by way of a circumambulation of the holy center spirally upwards to its very top decorated by many coloured Buddhist prayer flags.

On this hill-top there is a small gompa. According to various information gathered at the locality 18 this gompa is only about 13 years old (and its construction had seemingly caused strong conflicts within the - Hindu - village community leading even to an attempt to demolish it). Nowadays the lama is the owner of the whole hill. He has prohibited hunting and the cutting of trees on this terrain. Currently he intends among other projects to build a new and bigger gompa including a pilgrim's guesthouse with the financial support both of widely respected high Tibetan lamas and of Westemers. Thus the recent Buddhist activities at Halase initiated by Tshopel Lama provide an illuminating example of the significant processes of Buddhist revitalization to be witnessed currently not only within the realm of Nepal but also in Sri Lanka, Thailand, Taiwan, Japan, and in some Westem countries.

We arrived at this hill-top shortly before sun-set on the night before Shivaratri. Orientation at the place was not difficult even to those who had arrived for the first time. A steady flow of several hundreds of Hindu devotees back and forth through the gate right next to the gompa strung with bronze bells clearly indicated the pilgrims' goal albeit hitherto still being invisible.

A personal impression may suffice to convey an idea of the specific atmosphere reigning down there among the (Hindu-) pilgrims gathered in combination with the impressive size of Maratika cave. After ringing the numerous bells we passed through this gate. At the threshold the constant sound of these bells met with thick clouds of incense in combination with a loud mix 
of human voices and of the high-pitched screaming of thousands of bats coming up in waves from a dark pit.

From here one has to proceed on fairly newly built greyish steps made of cement on the way down, the goal being still invisible (formerly these steps were black stone steps carved into the hillside, some experienced pilgrims told me). Continuing the downward climb it becomes increasingly dark. This creates the impression of descending into a well but the goal remains still out of sight. All of a sudden, as if by shere magic, one is able to realize that one has reached something like a platform which constitutes the floor of an enormous cave. In size this cave equals a huge hall or auditorium.

As mentioned before I visited this site on the night of Shivaratri in the company of the group of Sherpa pilgrims from Ringmo. Some hundreds of festively dressed Hindu pilgrims had assembled there for the night in order to be in closest contact with the venerated deity. Obviously several groups had come in closest contact with the venerated deity. Obviousi'. The bottom of the cave was to Hale completely packed by the numerous and dive was hardly any room to move, but reciting prayers, bu was a constant coming and going of happily smiling and nevertheless there was a constant coming and fires were burning the flames of which were throwing flickering Bahun-Chhetris, Limbus and Rais take part in this pilgrimage. But in this situation the observing eye just being overwhelmed by the sight of an immense mass of gaily interacting - within their group, at least - and very nicely dressed pilgrims was not capable of making out the many differences (ethnic, linguistic, gender and age) which set them apart from each other in normal everyday life.

It took us quite a while to make our way as curious visitors down to the bottom of the cave. But due to the mass congregation of Hindu pilgrims in closest proximity of the venerated deity we finally had to return up again. - This and the following two nights we slept in the courtyard of the house of a widely respected old Brahmin widow in the vicinity of Maratika cave. Other places where Sherpa pilgrims use to spend the night during their stay at Halase are in or around the gompa or on a small strip of terraced ficld on the other side of the bazaar on the bottom of the hill which was used as camping ground.

On the morning of the following day all the Hindu pilgrims who had gathered at the bottom of this cave for that one night had left the holy site. Apart from several big heaps of garbage already piled up there were no remnants reminding of the huge gathering of Hindu pilgrims in the night before. Now it was time for those Buddhist pilgrims already present to discover the interior of the holy cave. This was usually done not individually but in those social groupings the various participants had formed when leaving for a pilgrimage. In all cases recorded those social groupings consisted of parts of an extended family and/or of individuals belonging to the same locality.

Those diverse social groupings kept on dropping in to Halase in the course of the following two days. The number of participants over the days of festival was in constant flux. This phenomenon seems to be a central feature of pilgrimage events making any 'exact' counting of those pilgrims present at one specific site or of all the pilgrims during a specific pilgrimage a difficult if not an impossible task. Some participants had several days to spend there, whereas others only came for the length of one or two nights before returning home again. Their main aim was to visit the holy site and to spend some time there for religious purposes. To this of course, add some seemingly quite profane purposes like enjoying the various mundane offers in the local bazaar run during times of pilgrimage.

Excessive drinking of rakshi and chang by men and women alike often inviting Sherpas from other groupings was a common theme. Old people especially, both women and men appeared to be tough, happy, and controlled drinkers. Usually they stuck to chang which traditionally is regarded as drink only being consumed in the context of religious festivities. Not infrequently one could encounter an aged person who probably had got importance for a while being led by a young kid to the next place of importance for the grouping he or she belonged to.

Apart from circumambulating the whole mountain, the interior of Maratika cave seems to be of special interest to the Sherpa pilgrims observed on the spot. It is 'discovered' on one of the days before 'losar' in order to perform poojas, to recite sacred formulas, and to direct prayers individually to the deities connected with the holy locale. Through the sacred realm the pilgrims move accoding to an itinerary arranged to reflect upon the power of Buddhism and the venerated deities, the surmount obstacles, and to test and to prove he strength of their faith.

Down there it is black and damp and it takes a while until in this dimly lit place the eye is able to provide usual visual orientation. The intense smell of waves of incense and the squeaking sounds of thousands of bats high above underneath the impressive 'ceiling' of this site add more specific flavor to the important gathering. 
In this context orientation in the process of personal discovery is extremely difficult. On the one hand one rarely gets a clear overview over the whole structure of the holy cave because of its various specific geological formations - if one tries to take photos one object usually hides many others. On the other hand while discovering this only dimly lit site there are so many instances to distract the gaze of the observing eye. As everything was new to the whole group of Sherpas I was travelling with - but not to me - I observed that everyone for a short but interesting moment seemed to encounter the same difficulties in exploring this wholly unknown terrain. Finding ourselves finally down there in our group of pilgrimage among several other sherpa groups everyone of us seemed to sense just a very short moment of insecurity as to what to do now, where to start the inner circumambulation, in which sequential order the various important places are to be visited etc. - This individually felt disorientation occured for a short time until the eye got adapted to the dim light. It seems to be noteworthy in that it represents an essential feature of what in the realm of current theoretical discourse drawing considerably on the work of the Belgian folkloirst Amold van Gennep is considered as a 'rite de passage': According to van Gennep the whole of the socio-religious process of pilgrimage represents one of the foremost important examples of a 'rite de passage'.

That short moment of individually felt insecurity did not last long. Many corners of the cavern were dark and obscured. The central area and most of the sacred spots, however, were fairly well illuminated by the countless butter lamps and was candles being offered by pilgrims. Looking around one's gaze met with the same disoriented gaze of fellow pilgrims, and in doing so everyone of us immediately realized other groupings present already being in the midst of the practice of circumambulating the site. This finally provided the orientation necessary as to know where to start from, what to do where, and where to end this ritual practice. At this moment there were present only three groups of Sherpa pilgrims, one Hindu family, one Hindu sadhu, and some playing children. The sadhu seemed to enjoy fulfilling something like the role of a pilgrim's guide around the various sites on the bottom of the cave. He informed those present from a Hindu point of view - on the history of the many strange stone formations which make up the distinctive feature of this sacred center.

The groups clustered in several parts of the platform. Each group engaged in performing their own rituals sticking to the prescribed sequence of circumambulation of the interior holy site in clockwise direction. It must be emphasized here that most of those rituals are not performed collectively within one's group. And there are no shrine officials who would guide the devotees through this sacred space and interpret the meaning of Maratika cave, thus controlling the performance of the diverse rituals held there. In consequence of this lack of institutionalized religious power the pilgrims are largely free to wield their own power to pursue ritual practices according to their own designs (which were, of course, informed by the official discourse and its prescribed procedures):

In most cases witnessed one could see individuals standing in front of one of the various rock formations who were deeply involved in their own prayers and prostrations. While praying and prostrating the touching of those natural formations with their body repeatedly, especially with hands and head, seemed to be an essential feature of the rituals performed here individually. Meanwhile the other members of the pilgrim's group stood waiting for their own term to begin with. Pilgrims could be observed chatting gaily and watching curiously other pilgrims' ways of handling the obstacle courses to come. But one could also observe individuals in deep contemplation.

Some of the young Sherpani seem to be very keen upon getting hold of one of the sparsely water-drops falling onto the 'linga'. We made our various obeisances and proceeded to explore and identify important points of the Halase cave. Each rock seemed to enjoy a distinctive identity and to all of them was attributed some degree of sanctity. The Hindu sadhu as well as pilgrims of other groups kindly invited us to test the strength of our faith by attempting the obstacle courses - another central characteristic of not only this pilgrimage place - in this arena. Thus we had to squeeze our bodies on two occasions between two stalagmite pillars only about ten inches apart; on two other occasions we had to disappear into a small hole in the ground and to creep through this in order to reappear in another hole in the ground just a few meters apart; and each of us had to ascend a narrow ledge on the wall of the cave in order to enjoy the blessing of the reliquiary lodged there in the wall above. Of such a kind were the various tests concerning the pilgrim's strength of faith.

According to a learned monk staying at the gompa all these different tests result in creating an obvious division between heaven and hells, good and bad and religious and non-religious persons. It has to be mentioned, though, that the decision upon testing the strength of one's faith by trying to squeeze oneself through the numerous obstacles at this site seems to be reached by the individual pilgrim alone. Having been occupied in thiscontext predominantly by participating in those different tests thus representing a cause for permanent laughter among the fellow pilgrims my capacity for observing at the same time was quite restricted. Anyhow I did not witness any kind of 'moral force' exercised either by 
specific persons or by the group as a whole in order to ke a hesitating or nonwilling person undergo those tests of individual aith. However, with the exception of the old people all - younger - members of a group of Shepa pilgrims seemed to be eager to do so.

The interspace between the realm of the 'sacred' and that of the 'profane' does not seem to be clearly delimited in this context. It can only be sensed when witnessing certain practices of the Sherpa pilgrims. Those do not constitute part of the religious rituals performed at Maratika cave but they are nevertheless an integral part of the pilgrimage process. The rectangular paved space giving access to the gate down to the cave as well as to the gompa seems to be the stage for the performance of certain 'social' rituals of importance to Sherpa communities. Here Sherpas, especially old and young Sherpanis of various groups join together dressed in their best festive clothes and perform their dances at night. And this is also the social space for the wealthy to distribute food, 'chang' and home-brewed 'rakshi' being carried all the way down to this place of pilgrimage to the public. Whereas this corresponds to existing social norms in reality those individuals who are offered something on this occcasion are carefully selected. This seems to constitute one of the various social occasions I witnessed in different contexts which are used by Sherpas of high status for their own self-enactment in public.

This paved yard in front of the gate and the gompa as well seems to be the only social space within the realm of the sacred center where on special occasions the diverse pilgrims present create for but a short while a social situation which comes close to what V. Turner categorized as 'communitas'. But this is only the one side of the coin. On the other hand the distribution of food and alcoholic drinks by wealthy Sherpas to the public on festive occasions represents wholly selfish interests. By doing so the distributor gains merit and enacts his or her status at the same time. In performances of that kind there seem to co-exist opposing social forces like solidarity and self-interest, 'communitas' and status.

The climax of the ritual processes taking place at Halase during the Buddhist pilgrimage on occasion of 'losar' seems to be the big pooja on the morning of the Tibetan New Year usually performed by the lama of the small Halase gompa. But in consequence of his absence due to grave illness in this year there was no lama to preside over and to perform that final pooja. After that there happen to take place seemingly never ending gay talks among the various Sherpa pilgrim groupings. Usually this is connected with much drinking offered by some of the women of the diverse groupings present. This is another situation when 'communitas' can emerge for a limited time but that is restricted only to Sherpa pilgrims who come from different localities. When this kind of social interaction between the groups finally comes to an end time has come to start the journey back home. In comparison with the Hindu pilgrim faction coming to this holy center on a fixed date and just for the length of one day and one night - most of them, in fact, only for the night - the agenda of the diverse Buddhist pilgrim groupings seemed to be far more flexible.

If the Western participant observer is allowed to specify the most remarkable feature of this pilgrimage experience from his personal point of view, I have to emphasize the distinct atmosphere reigning at Maratika cave in the course of this Buddhist pilgrimage. It can easily be summarized as peaceful and relaxed and seemingly free from any serious tensions. It must be added, though, that the same holds true of the Hindu pilgrimage three days before. In my opinion this was due to pilgrims who were above all curious about the place notwithstanding the presence of pilgrims of another creed, ready to be impressed by its mysteries, and eager to gain the fruits of its promises to faithful pilgrims.

\section{Conclusion: 'Plurality of Discourses', 'Status and Communitas'}

The article is concerned with the detailed study of the movement of Sherpa pilgrims from Solukhumbu to and at a particular place which as a manifestation of the divine is considered as imbued with the sacred. Instead of aiming at vast generalizations a la Turner and his disciples ${ }^{19} \mathrm{I}$ am interested in presenting the findings gained in the course of investigating a particular case study.

The organization of rituals and the interaction of pilgrim groups with diverse imaginings of Halase illustrates the complex interweavings of different religious discourses typical of this place of pilgrimage. Maratika cave apparently emanates an intrinsic religious significance of its own which is illustrated by two different textual traditions. The holy center provides a religious space for the expression of a diversity of perceptions. It is achieved through ritual performances which are shaped by religious and political, regional and national, ethnic as well as class backgrounds. At play in this specific context are definitely not only locally founded individual forms of both 'folk' and orthodox 'high religion'.

Striking to me as a Western participant observer was the fact that the coexistence of different religious discourses concerning the sacred locale, its origins, significance and powers, thus validating different sets of devotional practices, does not lead to any clash of conflicting perceptions. In consequence 
of these crucial aspects the holy center of Halase seems to represent a socioreligious space capable of accomodating diverse ideas, concepts, meanings, and practices.

The particular Sherpa pilgrimage to Maratika cave on occasion of 'losar includes both an interesting field of social relations and a realm of co-existing discourses that seemingly do not compete for supremacy. It must be emphasized, however, that the research results gained in the context of the Sherpa pilgrimage to Halase do not seem to lend themselves to any sort of generalization. If one tries to identify the specific features of this pilgrimage it is the seemingly easy coexistence of solidarity and self-interest, of communitas and status all of which are played out in its course. However, a particular aspect like 'communitas', dominating the whole of the pilgrimage process, cannot be singled out in this framework. On this occasion existing social boundaries do not really seem to be transcended; according to my informations the individual pilgrim's outlook onto the world does not seem to have changed fundamentally in the course of a pilgrimage experience. On the contrary, one may safely assume that its experience rather results in the maintenance and even the reinforcement of social distinctions and boundaries. It is this phenomenon that can be considered as the 'social function' of pilgrimage as an important socioreligious institution.

The picture outlined is based upon key metaphores such as 'plurality of discourses', 'status and communitas', 'crisis? - no serious 'crisis!', and 'maintenance and reinforcement of ethnic distinctions and social boundaries'. Nevertheless, the presented results do not seem to be too illustrative as to the very particularity of the Buddhist pilgrimage to maratika cave.

Due to the various continously elaborated theoretical concepts and the ongoing refinement of methodological approaches recent research into the topos of pilgrimage has viewed this world-wide phenomenon from a variety of perspectives. Accordingly in order to gain a representative insight into the complexity of the diverse aspects involved in constituting the particular pilgrimage process to and at Maratika cave different perspectives onto the same topic have to be put into play.

These perspectives include questions like 'site, power, and administration', 'diverse groupings forming the cultic constituency of the holy center', 'differences in the pilgrims' perception of the sacred locale usually based on 'local knowledge', 'the complex and often ambivalent attitudes of locals towards Maratika cave and its cult' etc. Detailed comparisons with pilgrimages to other holy sites offer another approach which might both add insight into the chosen field and to differentiate the chosen perspective.

\section{FOOTNOTES}

1. This investigation is part of a larger research project on Sherpa Buddhist pilgrimage sponsored by the Swiss National Science Foundation. The article is dedicated to Barbara N. Aziz, to whom I owe many valuable inspirations.

2. A. W. MacDonald was the first to remind the scientific community of this fact and to encourage adequate research into Halase as an important place of pilgrimage. K. Buffetrille-Daum mentions Halase in her 'Rapport de Mission au Nepal' (p.-2). - Recently Namkhai Norbu has published an article on 'The Pilgrimage to Maratika' in his anthology 'Dream Yoga and the Practice of Natural light', ed. and introd. by M. Katz. Ithaca, N.Y.: Snow Lion Public. 1992, p. 73-89. I am grateful to F. - K. Ehrhard, Nepal Research Center, Kathmandu from whom I received this, but not only this, information !

3. On the history and religion of the Sherpas, see M. Oppitz. 1968; F.W. Funke 1968; D. B. Bista 1987; Sh. B. Ortner 1989.

4. Chr. v. Fürer-Haimendorf 1964 and 1984

5. On the latter Dudjom Rinpoche.

6. Chr. v. Fürer-Haimendorf illuminates this context: "The entire moral system (of the Sherpas) is dominated by the belief in merit and sin, as the two elements shapping their ultimate fate. Like other Buddhists, the Sherpas believe that every act of virtue adds to an individual's store of merit, whereas every sinful act diminishes this valuable store" (1984,p. 106). See also 1964 , pp. $272-5$.

7. On the importance of gaining merit in the general Tibetan cultural context R.A. Stein 1987, p. 115.

8. In the context of gaining 'merit' by way of religious activities Sh. Ortner ignores 'sonam' but refers instead to 'payin' seemingly meaning the same concept (1978:36-41; 1989:76-81). R. Kunwar takes her lead. But he 
specifies the purpse of 'phayen' which according to him does not differ from Ortner's understanding of 'payin' as 'piling merit for next life' (215). This concept implies the conscious transcending of inner-worldly goals by certain religious activities.

9. See MacDonald, p. 8.

10. See P.H. Prindle 1983, p. 114.

11. On this see B.N. Aziz (pp. 17-19). However, she does not explicitly name Halase in her book.

12. Due to this A.W. MacDonald has already pointed to the fact that more detailed observations in situ seem to be long overdue (see p. 5).

13. One of the numerous names of Lord Siva.

14. This is only one of the many caves in the realm of the Himalayas of Nepal where according to tradition Guru Padmasambhava has stayed at for meditation in retreat.

15. D. Snellgrove gives an illuminating account of Mandarava's childhood as the daughter of the king of Zahor. Moreover the specific circumstance are outlined which led Guru Padmasambhava realizing that 'she was a fitting pupil' to come through the air, to manifest himself to her and to give her religious instructions. After some tragic episode, Padmasambhava manifested himself to her father and finally 'accepted the king's offer of his kingdom and Mandarava as his bride' (see p. 173).

16. On the textualisation of 'cedrub gondus' in the eighth century, on the specific circumstances of its preservation by Guru Padmasambhava as a 'hidden treasure', and its rediscovery in the nineteenth century after a period of more than a thousand years see Namkhai Norbu (p. 89, Fn. 23). - L.A. Waddell mentions 'Halashi' in the context of the description of the 'Raksha' rosary formed of large brown warty seeds. This rosary is used especially by Nyingma-pa lamas in rituals worshipping the fierce deities and demons. Those seemingly abnormal seeds are said to be highly valued by Tibetans, "... who believe them to be the offspring of some seeds of Padmasambhava's rosary, which, the legend states, broke at his Halashi Hrmitage in Nepal ..." (p. 208).

17. C. Jest, see chapter 25 .

18. In the main I had a very informative talk with its founder Tshopel Lama, well known as Maratika Lama, on occasion of 'losar' 1992; and with some monks - two of them being sons of Tshopel Lama - who had been staying there over 'losar' 1993 due to the absence of the lama who had seriously fallen ill and had undergone treatment in Kathmandu at that time.

19. In opposition to the influential approach propagated by the Turners and their following I share the 'leitmotiv' for any research into the realm of pilgrimage in diverse cultural contexts articulated by the late M.J. Sallnow (p. 9):"... the most helpful, pre-analytic image to hold in mind is of a tangle of contradictions, a cluster of coincident opposites."

\section{BIBLIOGRAPHY}

Aziz, B. N.

1987

Bista, D. B

1987

Buffetrille-Daum, K.

1990

Dudjom, Rimpoche 1991

Funke, F. W

1969

Furer-Haimendorf, Chr, v.

1964
Tibetan Frontier Families: Reflections of Three Generations from D'ing ri. New Delhi: Vikas.

People of Nepal. Kathmandu: Ratna Pustak (orig. 1967). See pp. 160-68.

Rapport de Mission au Nepal. Unpubl. Ts. Paris: CNRS.

The Nyingma School of Tibetan Buddhism. Transl. and ed. by M. Kapstein and Gyurme Dorje. Boston: Wisdom Publications.

Religioses leben der Sherpa. Innsbruck and Munich: Universitatsverlag Wagner.

The Sherpas of Nepal. London: J. Murray. 
Jest, J.

1975

Kunwar, R. R.

1989

Dolpo: Communautes de Langue Tibetaine du Nepal. Paris: Ed. du CNRS.

Fire of Himal: An Anthropological Study of the Sherpas of Himalayan Region. Jaipur: Nirala Publications.

MacDonald, A. W. 1985

"Points of View on Halase, a Holy Place in East Nepal". The Tibet Journal, Vol. 10, No. 3, pp. 3-13.

Namkhai Norbu 1992

"The Pilgrimage to Maratika". In his anthology Dream Yoga and the Practice of Natural Light. Ed. and intord. by M. Katz. Ithaca, N. Y.: Snow Lion Publ.

Oppitz, M.

1968

Geschichte und Sozialordnung der Sherpa. Innsbruck: Universitatsverlag Wagner.

Ortner, S. B.

1978

1989

Prindle, P. H.

1983

Sallnow, M. J.

1987

Sherpas through Their Rituals. Cambridge and New York: Cambridge University Press.

High Religion: A Cultural and Political History of Sherpa Buddhism. Princeton, New York: Princeton Univ. Press.

Tinglatar: Socio-economic Relationships of a Brahmin Village in East Nepal. Kathmandu: Ratna Pustak.

Pilgrims of the Andes: Regional Cults in Cusco.
Snellgrove, D.

1957

Stein, R. A.

1987

Buddhist Himalaya: Travels and Studies in Quest of the Origins and Nature of Tibetan Religion. Oxford: B. Cassirer.

LaCivilisation Tibetaine (Edition definitive). Paris: L' Asiatheque (orig. 1962).

Waddell, L. A

1985

Buddhism \& Lamaism of Tibet. Kathmandu: Educational Enterprise (orig. 1894) Washington, DC: Smithsonian Institution. 